\title{
Solitary Spinal Dural Syphilis Granuloma Mimicking a Spinal Meningioma
}

\section{Spinal Menenjiyomu Taklit Eden Soliter Spinal Dural Sfiliz Granülomu}

Heng-Jun ZHOU, Ren-Ya ZHAN, Man-Tao CHEN, Fei CAO, Xiu-Jue ZHENG

First Affiliated Hospital, Zhejiang University, College of Medicine, Department of Neurosurgery, China

Corresponding Author: Xiu-Jue Zheng / E-mail: jhw_hz@163.com

\begin{abstract}
Dural granuloma is extremely rare. To our knowledge, there has no case reported solitary spinal dural syphilis granuloma worldwide so far. Here we report our findings in a 49-year-old woman, who presented with 10-year progressive left lower-limb numbness and two weeks of right lower-limb numbness. Magnetic resonance imaging (MRI) suggested a homogeneous enhanced spindle-shaped lesion, $2.9 \times 1.5 \mathrm{~cm}$ in size, occupying the spinal intradural extramedullary space, at the level of Thoracic ( $T$ )-2/3, which mimicked the appearance of spinal meningioma. The Treponema pallidum particle agglutination (TPPA) test titer of 1:8, and the venereal diseases research laboratory of cerebral spinal fluid (VDRL-CSF) was reactive, so confirmed neurosyphilis was considered. After formal anti-syphilis treatment, posterior laminectomy surgery was performed, and the lesion was completely separated and extirpated. Final histopathologic diagnosis of the lesion was confirmed as chronic granulomatous inflammation, combined with the neurosyphilis history, spinal dural syphilis granuloma was finally diagnosed. Postoperatively, the patient recovered without any further treatment.
\end{abstract}

KEYWORDS: Spinal dural syphilis granuloma, Neurosyphilis, Meningioma, Granulomatous inflammation, Granulomatous nodules

öz

Dural granülom çok nadirdir. Bildiğimiz kadarıyla daha önce bildirilen bir soliter spinal dural sifilis granülomu olgusu yoktur. Burada, 10 yıldır progresif sol bacak uyuşukluğu ve iki haftadır sağ bacak uyuşukluğu ile gelen 49 yaşında bir kadın olguyu sunuyoruz. Manyetik rezonans görüntüleme (MRG) Torasik (T) -2/3 spinal intradural ekstramedüller boşlukta spinal menenjiyoma benzer bir şekilde yer alan 2,9 x 1,5 cm büyüklüğünde ve homojen kontrast madde tutan mekik şekilli bir lezyon gösterdi. Treponema pallidum partikül aglütinasyonu (TPPA) testi titresi 1:8 bulunduğu ve venereal hastalıklar araştırma laboratuvarı testi beyin omurilik sıvısında (VDRL-BOS) reaktif olduğu için nörosifilis düşünüldü. Anti-sifilis tedaviden sonra posterior laminektomi cerrahisi yapıldı ve lezyon tamamıyla ayrılıp ekstirpasyon gerçekleştirildi. Lezyonun son histopatolojik tanısı kronik granülomatöz enflamasyon olarak geldi ve nörosifilis öyküsüyle birleştirildiğinde son tanı spinal dural sifilis granülomu oldu. Postoperatif olarak hasta başka tedavi gerekmeden iyileşti.

ANAHTAR SÖZCÜKLER: Spinal dural sifilis granülomu, Nörosifilis, Menenjiyom, Granülomatöz enflamasyon, Granülomatöz nodüller

\section{CASE ILLUSTRATION}

A 49-year-old woman presented to our clinic with a 10-year history of progressive left lower-limb numbness with no clear trigger. She also suffered right lower-limb numbness that began approximately two weeks prior to entering the clinic. Since the onset of numbness in both lower limbs, she had been unable to walk steadily and required help. Her proprioception and fine tactile sensation were both impaired below the chest, with the right side more seriously affected. A syphilis serology test was positive, with a Treponema pallidum particle agglutination (TPPA) titer of 1:8. Lumbar puncture was performed, and the venereal diseases research laboratory of cerebral spinal fluid (VDRL-CSF) test was positive. Magnetic resonance imaging (MRI) indicated the presence of a homogeneous enhanced spindle-shaped lesion, $2.9 \times 1.5 \mathrm{~cm}$ in size, occupying the spinal intradural extramedullary space, at the level of thoracic (T)-2/3, which mimicked the appearance of spinal meningioma (Figure 1AC). Considering these results, we determined that the solitary lesion compressed the spinal cord and that operation was the only way to relieve the neurological symptoms. In addition, asymptomatic neurosyphilis was diagnosed and treated before the operation.

After formal anti-syphilis treatment $\left(2 \times 10^{5}\right.$ units $/(\mathrm{kg} \cdot \mathrm{d})$, aqueous penicillin $\mathrm{G}$ and intravenous glucose tolerance tests (ivgtt) for 15 days, followed by $2.4 \times 10^{6}$ units/week benzathine penicillin given by intramuscular injection for three weeks; methylprednisolone was also used at early stages to avoid a Jarisch-Herxheimer reaction), the patient underwent a T-2/3 posterior laminectomy decompression. Microscopically, the lesion was split in two from the midline and looked like a flesh-colored "leech" crawling on the dura, with a soft texture, abundant blood supply, and a clear elliptical border (Figure 2A). Once this lesion was dissected from the dura, the relationship between the lesion and dura became apparent. The lesion reached from the intradural space to the extradural space, while leaving the affected dura mater intact (Figure 2B). It was completely and microsurgically dissected from the dura 
mater, and the corresponding lamina arcus vertebrae were removed. The patient largely recovered from her lower-limb numbness and lower-limb lack of motility. During a four-year follow up period, the patient's syphilis serology and VDRL-CSF results all converted to negative, her limb numbness disappeared, and she regained her ability to walk normally (Figure $3 A-C)$. She remains in good health without further treatment.

Under the microscope, the syphilitic lesion consisted of granulomatous nodules of various sizes. It contained abundant epithelium-like cells featuring spindle cell morphology and round cell nuclei. Scattered multinucleated giant cells, fibrosis tissue, and inflammatory cells could also be seen infiltrating the nodules by hematoxylin-eosin (H-E) staining (Figure 4AC). Acid-fast staining was negative, and immunohistochemical staining indicated that the nodules were negative for vimentin, epithelial membrane antigen (EMA), S-100 protein, and CD34. These findings excluded the possibility of meningioma or schwannoma and were consistent with the diagnosis of spinal dural granuloma caused by Treponema pallidum.

\section{DISCUSSION}

Spinal dural syphilis granuloma, a particular type of chronic proliferative inflammation (2), is primarily spread through the blood, or in the case of neurosyphilis through the CSF, while
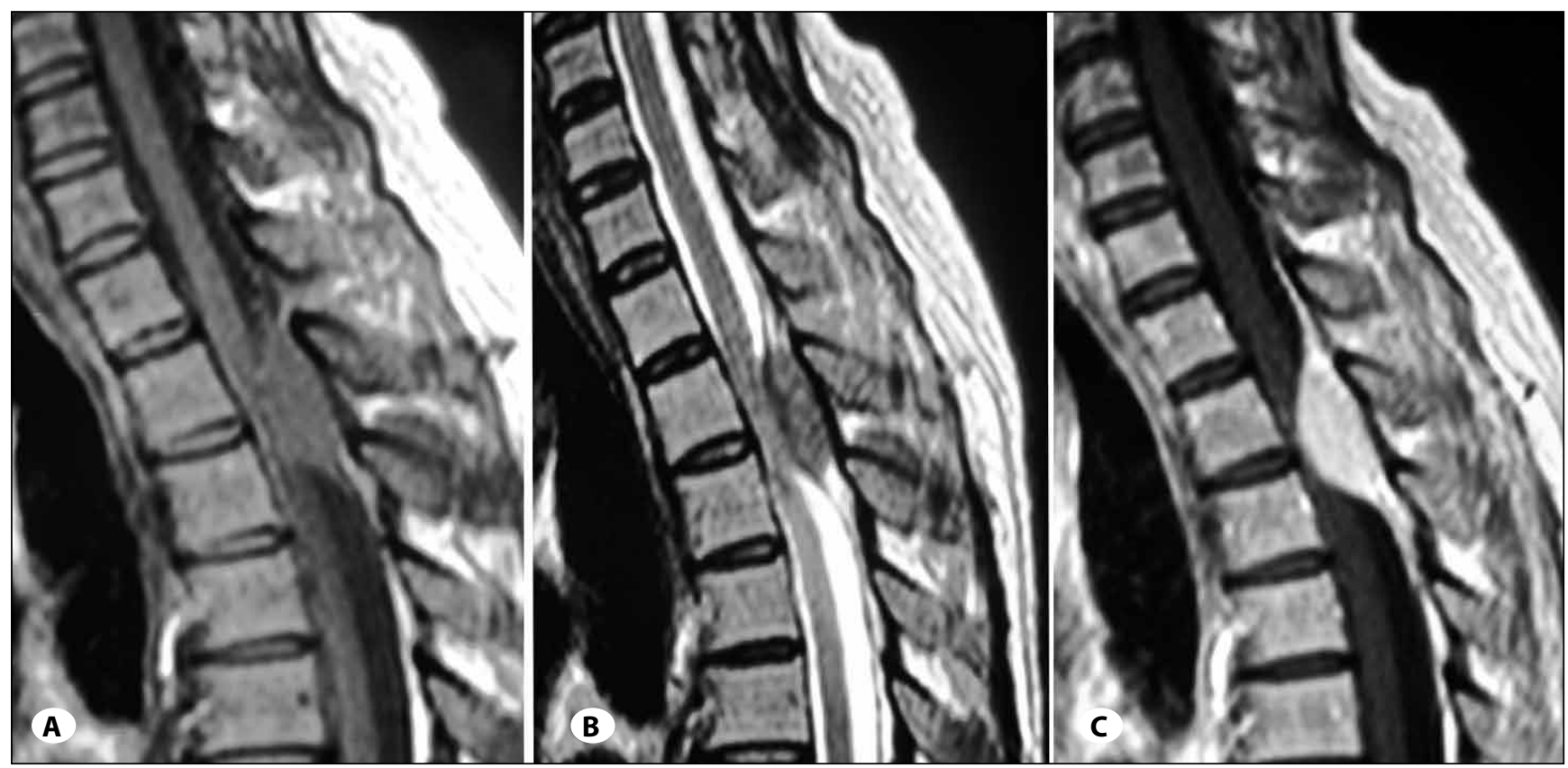

Figure 1: Preoperative spinal cord magnetic resonance imaging (MRI). A) (sagittal) T1 (Longitudinal relaxation time)-weighted image revealed a spindle-shaped lesion occupying the spinal intradural extramedullary space at the level of Thoracic ( $T$ )- $2 / 3$ was isointensity. B) (sagittal) T2 (Transverse relaxation time)-weighted image revealed the adjacent spinal cord was compressed and the adjacent subarachnoid space was widened. The signal intensity of the middle portion of the lesion was lower than either side. Specifically, the low signal portion was incrassated and had obvious internal migration, dividing the lesion into an external, large part and an internal, small part. C) (sagittal) Gadolinium diethylenetriamine pentaacetic acid (Gd-DTPA)-enhanced T1-weighted image revealed the spindle-shaped lesion was homogeneously enhanced, $2.9 \times 1.5 \mathrm{~cm}$ in size, which mimicked the appearance of spinal meningioma.
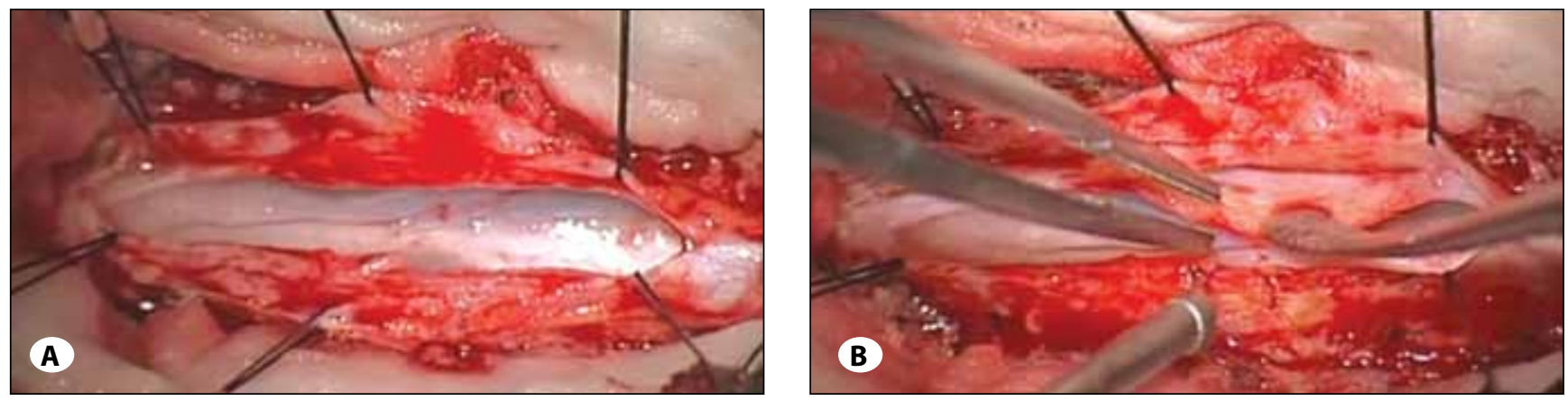

Figure 2: Intraoperative photograph. A) The lesion looked like flesh-colored "leech" crawling on the dura with soft texture, abundant blood supply and clear elliptic border, at the level of T-2/3. B) The lesion was dissected from the dura, it encroached from the intradural space to the extradural space with the dura mater in the middle. 

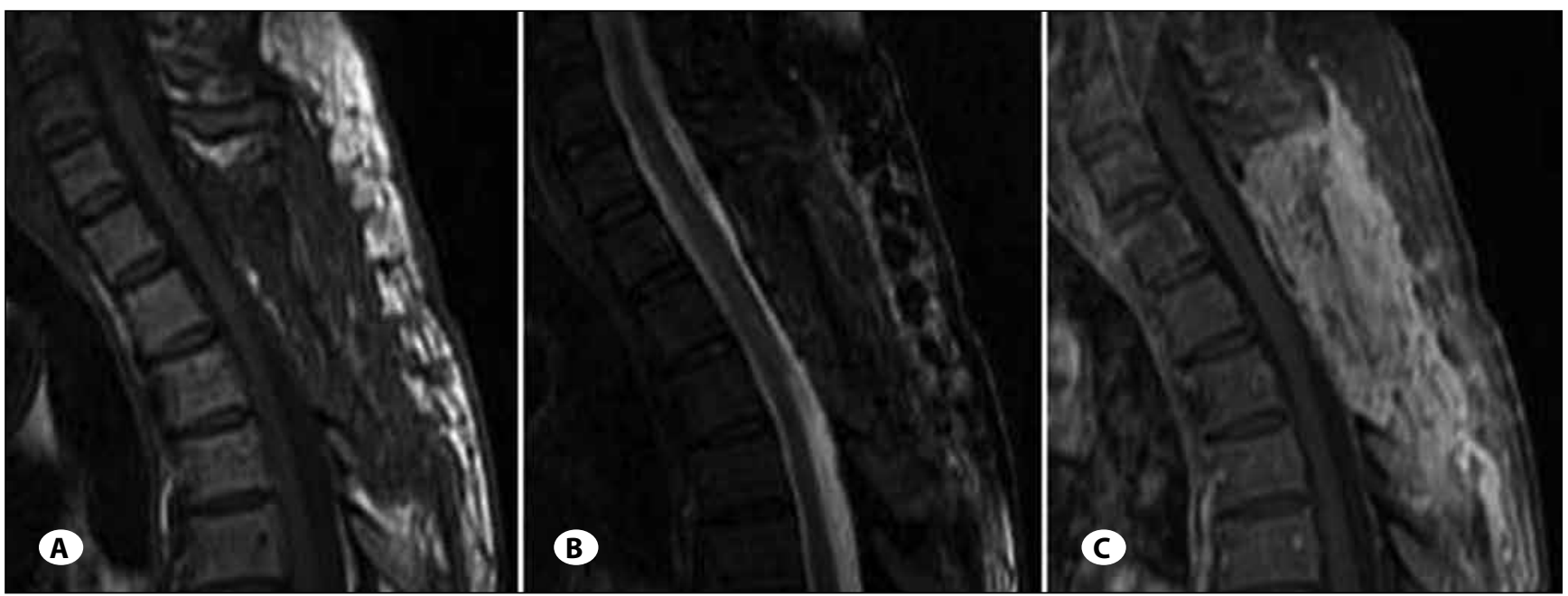

Figure 3: Postoperative spinal cord MRI. A) and B) (sagittal) T1-and T2-weighted images revealed removal of the spindle-shaped lesion and decompression of the adjacent spinal cord. The corresponding lamina arcus vertebrae was removed. C) (sagittal) Gd-DTPAenhanced T1-weighted image revealed no significant abnormal enhancement signal foci.
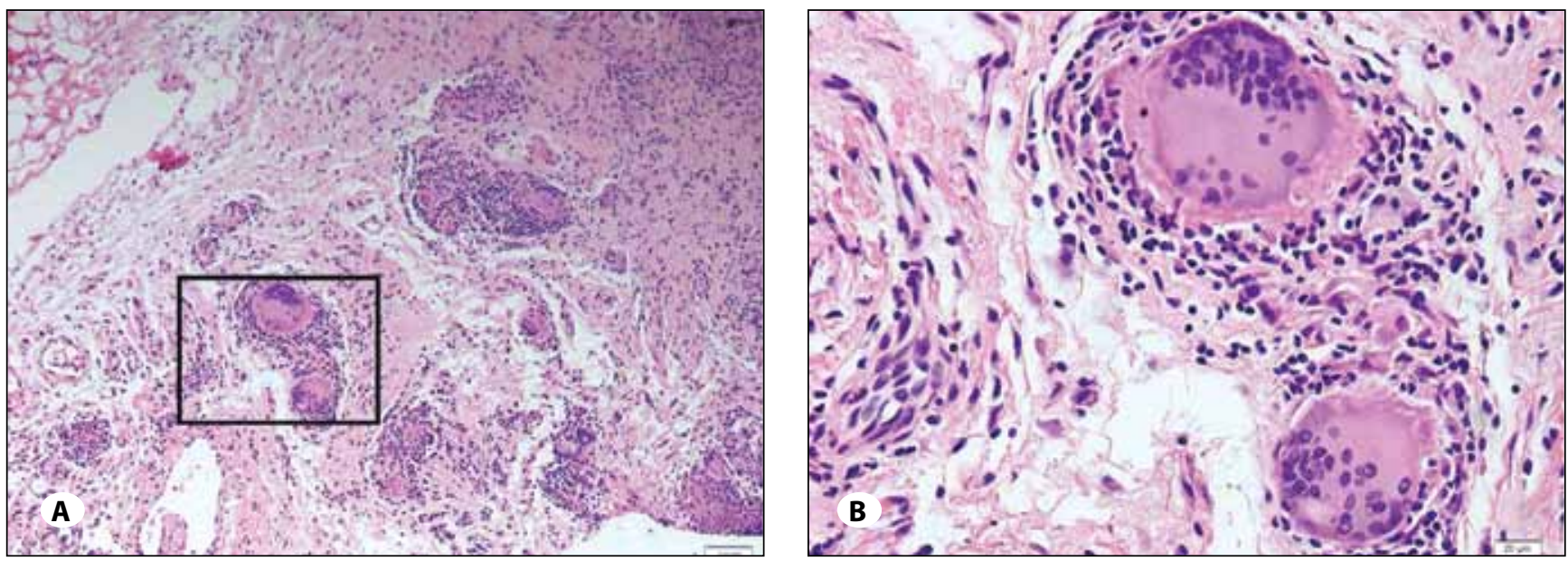

Figure 4: Postoperative histopathology. A) Various sizes of scattered granulomatous nodules were seen (hematoxylin-eosin (H-E) staining, $\times 100$ ). B) Enlarged part of the black box in A. The nodules contained abundant epithelioid cells, with multinucleated giant cell in the center, fibrosis tissue and inflammatory cells surrounded (H-E staining, $\times 400)$.

local spread may be due to tabes dorsalis (3). Cases have been reported among HIV-infected patients; however, in HIVnegative patients, it had never been previously reported (9).

Central nervous system (CNS) encroachment by the Treponema pallidum spirochete may occur at any stage of syphilis and does so with symptomatic manifestations such as meningeal syphilis, meningovascular syphilis, and parenchymatous syphilis (4). However, neurosyphilis can also be asymptomatic. The gold standard test to diagnose neurosyphilis remains under debate. A positive VDRL-CSF test is considered the most specific diagnostic criterion. Many syphilis patients with reactive VDRL-CSF have asymptomatic neurosyphilis, and clinical manifestations will develop in only a few (8). Our patient displayed nonspecific signs of a spaceoccupying lesion; meningioma was first (mis)diagnosed, but granuloma was finally confirmed by postoperative histopathology. Considering the positive syphilis serology result and reactive VDRL-CSF, neurosyphilis was considered, and spinal dural syphilis granuloma was the only possible diagnosis.

To our knowledge, this is the first report of spinal dural granuloma caused by Treponema pallidum. Its incidence in immunocompetent syphilis patients is unknown. This is extremely rare, and clinicians should consider the possibility of granuloma besides meningioma or schwannoma when they see a nonspecific clinical presentation with a solitary spinal dural spindle-shaped lesion.

Nevertheless, spinal meningiomas must be considered in differential diagnosis. Spinal meningiomas account for approximately $25 \%$ of all spinal tumors and $7.5-12.7 \%$ of all meningiomas (10). The most common presenting symptoms 
are pain, sensorimotor deficits, and sphincter disturbances, as such lesions always compress the spinal cord. In our patient, some features of the lesion misled our initial diagnosis: (1) Imaging studies characteristically revealed a solitary spindle-shaped lesion compressing the spinal cord forward, occupying the spinal intradural extramedullary space; (2) On T1-weighted images, the lesion appeared isointense with the spinal cord; (3) The lesion was homogeneously enhanced with apparent dural tail sign on T1-weighted images. At the same time, some findings were not consistent with those of meningioma. On T2-weighted images, the signal intensity of the middle portion of the lesion was lower than either side. Specifically, the low signal portion was incrassated and had obvious internal migration, dividing the lesion into an external, large part and an internal, small part. Definitive differentiation was a comparison of histopathological characteristics. Microscopically, the cardinal histological features of granuloma were aggregation of macrophages that were transformed into epithelium-like cells, surrounded by a collar of mononuclear leukocytes, principally lymphocytes and occasionally plasma cells (2). However, a preparation of a spinal meningioma will exhibit classical meningioma cells with positive staining for EMA protein (6), which was not seen in our patient's specimen.

Spinal dural granuloma is a benign inflammatory proliferative lesion for which no optimal management treatment has yet been defined. The role of conservative treatment is still unclear, while surgical resection seems to be advocated by most authors $(1,5,7)$. Fatih et al. (5) reported a rare case of "foot drop", which was caused by spinal epidural brucella granuloma. They believe that surgical intervention should be the mainstay of treatment, and antimicrobial treatment immediately following surgery or, if already started, continued after the surgery, is valuable (7). Mehmet et al. (1) presented a patient with cervical cord compression caused by foreign body granuloma mimicking malignancy; after surgical resection, upper spinal cord compression symptoms were obviously relieved. Here, we first performed formal anti-syphilis treatment with subsequent laminectomy to dissect the dural granuloma, which obviously improved the clinical symptoms during a four-year follow up period. Our results indicated that surgery may be a valuable strategy in patients with a solitary responsible lesion, and clinicians should consider this treatment strategy when confronted with solitary spinal dural syphilis granuloma.

\section{CONCLUSIONS}

To our knowledge, this is the first reported case of solitary spinal dural syphilis granuloma presenting as limb numbness in an immunocompetent syphilis patient. Clinicians should consider the possibility of dural granuloma besides meningioma or schwannoma when they see a solitary spinal dural spindle-shaped lesion. Formal anti-syphilis treatment followed by surgical resection is a valuable strategy for treating solitary spinal dural syphilis granuloma; more cases are needed to confirm this view.

\section{REFERENCES}

1. Ekici MA, Ekici A, Per H, Tucer B, Kurtsoy A: Foreign body granuloma mimicking upper cervical spinal mass after dural repair with tachocomp: A case report. Pediatr Neurosurg 46:133-137, 2010

2. Emile JF: Systemic granulomatosis. Anatomy/pathology of granuloma. Rev Med Interne Suppl 1:S4-5, 2005

3. French P: Syphilis. BMJ 334:143-147, 2007

4. Ghanem KG: Review: Neurosyphilis: A historical perspective and review. CNS Neurosci Ther 16(5):e157-168, 2010

5. Kökeş F, Aciduman A, Günaydin A, Kinikli S: A rare cause of "foot drop": Spinal epidural brucella granuloma. Turk Neurosurg 17:255-259, 2007

6. Lamszus K: Meningioma pathology, genetics, and biology. J Neuropathol Exp Neurol 63:275-286, 2004

7. Tekkök IH, Berker M, Özcan OE, Özgen T, Akalın E: Brucellosis of the spine. Neurosurgery 33:838-844, 1993

8. van Voorst Vader PC: Syphilis management and treatment. Dermatol Clin 16:699-711, 1998

9. Weinert LS, Scheffel RS, Zoratto G, Samios V, Jeffmann MW, Dora JM, Goldani LZ: Cerebral syphilitic gumma in HIVinfected patients: Case report and review. Int J STD AIDS 19:62-64, 2008

10. Wiemels J, Wrensch $M$, Claus EB: Epidemiology and etiology of meningioma. J Neurooncol 99:307-314, 2010 